\title{
Tinea Infection, an Encumbrance of the Year
}

\author{
Dr Avinash Shankar', Dr Amresh Shankar ${ }^{2}$, Dr Anuradha Shankar ${ }^{3}$ \\ ${ }^{I} M D$ (Internal Medicine); DNB (E\&M), Postgraduate in Endocrinology \& Metabolism (AIIMS-Delhi), \\ Chairman, National Institute of Health \& Research, Warisaliganj (Nawada) Bihar, 805130, India \\ ${ }^{2}$ BAMS (BRABU); MHA,Medical Officer, Bihar state Health Services, Director (Hon), Aarogyam \\ Punarjeevan, Ram Bhawan, Ara Garden Road, Jagdeopath, Baily Road, Patna 14 \\ ${ }^{3}$ BAMS (BRABU), Director, Centre for Indigenous Medicine \& Research, RA. Hospital \& Research \\ Centre, Warrisaliganj (Nawada) Bihar, 805130
}

\begin{abstract}
*Corresponding Author: Dr Avinash Shankar, MD (Internal Medicine); DNB (E\&M), Postgraduate in Endocrinology \& Metabolism (AIIMS-Delhi), Chairman, National Institute of Health \& Research, Warisaligani (Nawada) Bihar, 805130, India
\end{abstract}

\begin{abstract}
Dermatophytosis remain prevalent during 2016-2017 with recurrence or persistence in all the screened 3290 cases of either sex with male predominance and common among age group 25-40 years in spite of use of topical and oral available antifungal therapeutics, being considered as a result of increasing self-medication, drug misuse, climatic variation causing emergence of resistance to antifungal drug and decline in cell mediated hypersensitivity response to dermatophyte .
\end{abstract}

Keywords: dermatophyte, drug resistance, self-medication, cell mediated hypersensitivity response)

\section{INTRODUCTION}

Fungal infection of skin, a common agonising presentation of the year 2016-2017 and proved to be an year of fungal infection outbreak, as attendance of patients presenting with agonising itching increasing in geometric progression may be due to increased self-medication, use of OTC product and seasonal variation which prompted ecological alterance feasible for fungal growth and emergence of resistant fungal strain to commonly used antifungal agents both topical and oral. Fungal dermal infection affect all age group and both sexes. ${ }^{1,2}$

Thus with an intent to know the reason of this increasing incidence and non-response to commonly used therapeutics, patient attending at MOPD of RA Hospital \& Research Centre, Warisaliganj (Nawada) Bihar and Aarogyam Punarjeevan, Ara Garden Road, Jagdeo path Baily Road Patna 14 been screened.

\section{AIMS AND OBJECTIVES}

To ascertain the cause of increasing incidence of tinea infection and failure of conventional oral and topical antifungal drugs.

\section{Material AND MethodS}

Cases suggestive of fungal dermal infection either fresh or cases taking treatment without any response been selected, interrogated, for the disease onset, duration, complaints, treatment, onset, duration, complaints, treatment taken and their outcome. History of immunosuppressive or immune compromise state, HIV or Diabetes mellitus

Each patient dermal sample been evaluated for typing of the lesion and culture and sensitivity to know the pattern of effective antifungal drugs.

Dietary history, profession, personal habits were also elucidated to analyse the data and ascertain the factor responsible for persistence or recurrence of the lesion. 


\section{Method of Sample Collection: ${ }^{3,4}$}

Infected area wiped with $70 \%$ Ethanol skin scrapping, kept in sterile plastic container (Sterile Uricol,Himedia)

\section{Examination of KOH Mount:}

Sample(scrap) treated with $40 \% \mathrm{KOH}$ for 10 minutes on a glass slide and examined under microscope for presence of fungi under low power magnification)

Positive sample were processed for the isolation of Dermatophytes on Sabourds dextrose agar (SDA,

Himedia).

Urease Test: to determine the dermatophyte species .

Polymerase Chain Reaction (PCR) for fungal DNA

\section{OBSERVATION}

Selected patients were of age $<5$ yrs to $>55$ yrs and majority were of age group 25-40 years

Table1. Shows distribution of patients as per part involved, age and sex

\begin{tabular}{|l|l|l|l|l|l|l|}
\hline Age group & $\begin{array}{l}\text { Tinea } \\
\text { M }\end{array}$ & $\begin{array}{l}\text { Corporis } \\
\text { F }\end{array}$ & Total & $\begin{array}{l}\text { Tinea } \\
\text { M }\end{array}$ & $\begin{array}{l}\text { Crura } \\
\text { F }\end{array}$ & Total \\
\hline$<5$ & 18 & 16 & 34 & 11 & 02 & 13 \\
\hline $5-10$ & 27 & 22 & 49 & 09 & 08 & 17 \\
\hline $10-15$ & 30 & 29 & 59 & 14 & 08 & 22 \\
\hline $15-20$ & 80 & 58 & 138 & 24 & 14 & 38 \\
\hline $20-25$ & 157 & 89 & 246 & 52 & 20 & 72 \\
\hline $25-30$ & 208 & 131 & 339 & 109 & 79 & 188 \\
\hline $30-35$ & 199 & 143 & 342 & 99 & 38 & 137 \\
\hline $35-40$ & 312 & 150 & 462 & 120 & 41 & 161 \\
\hline $40-45$ & 89 & 56 & 145 & 52 & 22 & 74 \\
\hline $45-50$ & 81 & 40 & 121 & 30 & 20 & 50 \\
\hline $50-55$ & 76 & 50 & 126 & 45 & 20 & 65 \\
\hline$>55$ & 198 & 90 & 288 & 73 & 31 & 104 \\
\hline
\end{tabular}

Out of all 2113 were male and 1177 were female (Pie diagram) and 2349 and 941 were of Tinea Corporis and Tinea Crura respectively (Bar diagram)

\section{Pie diagram Showing Male Female composition}
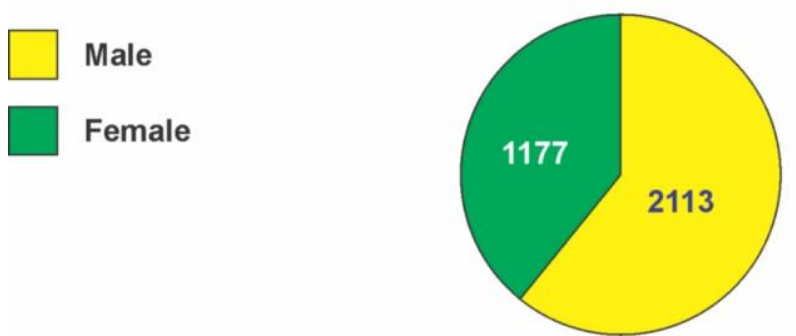

Bar diagram as per distribution of infection

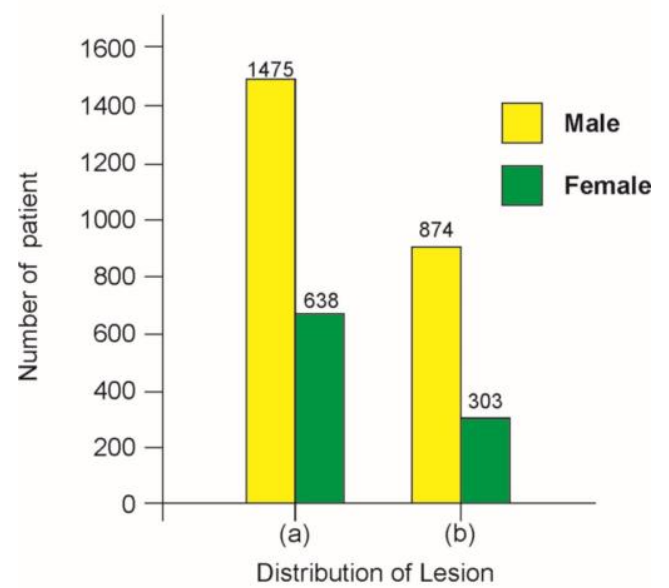

(a) $=$ Tinea corporis

(b) = Tinea Cruris 
Out of all 93.86\% (3088) patient were $\mathrm{KOH}$ positive, 94.9\% (3120) were urease positive while all 3290 cases shows DNA positive for dermatophyte

Table2. Showing diagnostic study

\begin{tabular}{|c|c|c|c|c|c|}
\hline \multirow{3}{*}{$\begin{array}{l}\text { Diagnostic } \\
\text { parameters }\end{array}$} & \multicolumn{4}{|c|}{ Number of patients } & \\
\hline & \multicolumn{2}{|c|}{ Tinea corporis } & \multicolumn{2}{|c|}{ Tinea cruris } & \\
\hline & Male & Female & Male & Female & Total \\
\hline $\begin{array}{c}\text { KOH staining: } \\
\text { Positive } \\
\text { Negative } \\
\end{array}$ & $\begin{array}{c}1390 \\
85\end{array}$ & $\begin{array}{l}598 \\
40 \\
\end{array}$ & $\begin{array}{l}804 \\
70 \\
\end{array}$ & $\begin{array}{l}296 \\
07 \\
\end{array}$ & $\begin{array}{l}3088 \\
202 \\
\end{array}$ \\
\hline $\begin{array}{l}\text { Urease: } \\
\text { Positive } \\
\text { Negative }\end{array}$ & $\begin{array}{c}1396 \\
79\end{array}$ & $\begin{array}{l}600 \\
38\end{array}$ & $\begin{array}{l}824 \\
50\end{array}$ & $\begin{array}{l}300 \\
03\end{array}$ & $\begin{array}{l}3120 \\
170\end{array}$ \\
\hline $\begin{array}{l}\text { PCR: } \\
\text { Positive }\end{array}$ & 1475 & 638 & 874 & 303 & 3290 \\
\hline
\end{tabular}

$31.61 \%$ patients were suffering with agonising presentation since $<1 \mathrm{yr}$ while $5.7 \%$ (186) cases since $>5$ years $(\mathrm{T}-3)$

Table3. Showing duration of illness

\begin{tabular}{|l|l|l|l|l|l|}
\hline \multirow{2}{*}{$\begin{array}{l}\text { Duration of illness } \\
\text { in years) }\end{array}$} & \multicolumn{4}{|c|}{ Number of Patients } & \multirow{2}{*}{} \\
\hline & \multicolumn{2}{|c|}{ Tinea corporis } & \multicolumn{2}{c|}{ Tinea cruris } & \\
\cline { 2 - 6 } & Male & Female & Male & Female & Total \\
\hline$<1$ & 418 & 209 & 312 & 101 & 1040 \\
\hline $1-2$ & 339 & 148 & 194 & 70 & 751 \\
\hline $2-3$ & 276 & 136 & 129 & 50 & 591 \\
\hline $3-4$ & 186 & 68 & 145 & 42 & 441 \\
\hline $4-5$ & 132 & 57 & 60 & 30 & 279 \\
\hline$>5$ & 124 & 20 & 34 & 10 & 18 \\
\hline
\end{tabular}

Out of all 28.8\% (948) had taken all sorts of topical and oral antifungal and their combination while other major group 18.2\% (600) has used only topical application.

Table4. Showing distribution of patients as per therapeutic status

\begin{tabular}{|l|l|l|l|}
\hline Therapeutic used & \multicolumn{3}{|c|}{ Number of Patients } \\
\hline & Tinea corporis & Tinea cruis & Total \\
\hline $\begin{array}{l}\text { Only topical application } \\
\text { Clotrimazole topical+ }\end{array}$ & 400 & 200 & 600 \\
\hline $\begin{array}{l}\text { Fluconazol Oral } \\
\text { Clotrimazole topical + }\end{array}$ & 294 & 140 & 434 \\
\hline $\begin{array}{l}\text { Itraconazol oral } \\
\text { Terbinafin topical + }\end{array}$ & 272 & 114 & 386 \\
\hline $\begin{array}{l}\text { Fluconazol Oral } \\
\text { Terbinafin topical + }\end{array}$ & 184 & 121 & 305 \\
\hline $\begin{array}{l}\text { Itraconazol oral } \\
\text { Topical coal tar \& } \\
\text { Salicylicacid + }\end{array}$ & 201 & 101 & 302 \\
\hline Fluconazol/itraconazole & 292 & 103 & 395 \\
\hline $\begin{array}{l}\text { Taken all shorts of topical } \\
\text { And oral }\end{array}$ & 550 & 398 & 948 \\
\hline
\end{tabular}

\section{RESULT}

Out of all screened cases of Tinea having used majority of available antifungal drug both oral and topical, but all presented with recurrent dermal infection.

\section{DISCUSSION}

Infection of keratinised tissue is caused by various fungi species and is assuming greater significance due to excess use of immunosuppressive drugs and self medication and commonest fungal infection is referred as Ring worm due to its ring like appearance and named as per part involved. 
Though this infection is prevalent globally, more common in tropical area and reaches epidemics in area with higher humidity, over population and poor hygiene. Hot and humid climate prompts dermatophyte infection. ${ }^{5,6}$

Commonly used drugs Fluconazol, Itraconazol, Terbinafin both as oral and topical and Clotrimazole as topical was quite in vogue, though topical agents like tolnafate, Salicylate and others are in use but non ensured cure except transient relief

In spite of use of available various therapeutics both topical and oral persistence or recurrence of dermatophyte infection in screened 3290 cases with male predominance and commonly affected age group 25-40 years, were positive for DNA typing of fungal infection, $\mathrm{KOH}$ staining and urease test.

Topical Azole inhibits Lanesterol-14 alpha demethylase, the enzyme CytP450 dependant enzyme convert Lane sterol to Ergo sterol make the fungal cell membrane unstable and cause membrane leakage

While Allylamine (Terbinafin) inhibit Squalene epoxidase which converts Squalene to Ergosterol and cause fungal cell membrane leakage

These drugs bind effectively to Stratum corneum due to its depolarising nature and penetrate deep to hair follicles.

AZOLE -----------(-) Lanestrol 14 alpha demethylase (CytP450 dependant enzyme)

Lanosterol ---------- $\rightarrow$ Ergosterol

\section{Causes fungal membrane unstable}

Allylamine------(-) Squalene Epoxidase

Squalone ---------- $\rightarrow$ Ergosterol

Membrane leakage

(Figure showing Biokinetics of antifungal resistance)

Thus the observation can be explained as ${ }^{7,8}$

- Male predominance may be due to increased out door exposure and more physical work leading to increased sweating synergized with less cosmetic concern than female.

- Secondly predominance dermatophyte infection among adult age group is due to increased level of physical activity and favors dermatophyte growth. In addition tightly worn synthetic cloths also causes localized humidity and body temperature facilitate suitable environment for dermatophyte growth. But in hard working female the incidence is at par with male.

- Chronicity and persistence of the infection is considered due to decreased cell mediated immunity and delayed hypersensitivity response to dermatophyte antigen and emergence of cross resistance to varied topical and oral antifungal.

\section{REFERENCES}

[1] Sahoo, Alok Kumar; Mahajan, Rahul Manifestation of Tinia corporis and Tinia crura and Tinea pedis, A comprehensive review, Indian Dermatology 2016:7(2):77-86

[2] Verma Shyam; Madhu,R; The great India epidemics of suerficial dermatophytosis, an appraisal, Indian journal of Dermatology (2017):62(3):227-236

[3] Sharma.Y; Jain. S; Chandra. K; Khurana. VK; Kudesia M; Clinico mycological evaluation of dermatophytes and non dermatophytes isolation for various clinical presenation, J. Res. Med Science 2012:17:817-918

[4] Kumar P Ganesh,Hemamalini, M; Lakshman, A; Madhavan, R and Ram mohan, S; Epidemiological \& Clinical pattern of dermatomycosis in rural india, Indian journal of Medical Microbiology (2015):33(5): 134-136

[5] Gupta AK; Tomar E; New antifungal agent, Dermal Clinic 2003:21:565-576

[6] Havlickova. B; Czaika.VA; Friedrich M; Epidemiological trends in skin mycosis world wide 2008:5(suppl 4) $2-15$ 
[7] Panda Saumya; Verma Shyam The meanace of dermatophytosis in India, the evidence that we need, IJDVL (2017):83(3):281-284.

[8] Verma. S; The Great Indian Evidence of superficial dermatophytosis, an appraisal NCBI-NIH, 2017

Citation: A. Shankar et al., "Tinea Infection, an Encumbrance of the Year", International Journal of Clinical Chemistry and Laboratory Medicine (IJCCLM), vol. 4, no. 1, pp. 9-13, 2018. http://dx.doi.org/10.20431/24557153.0401003

Copyright: (C) 2018 Authors. This is an open-access article distributed under the terms of the Creative Commons Attribution License, which permits unrestricted use, distribution, and reproduction in any medium, provided the original author and source are credited. 